\title{
ADDING VALUE WITH EXPERIENCES: INDUSTRIAL TOURISM AND GEOTHERMAL FOOD PRODUCTION
}

\author{
Barbara Pavlakovič \\ Maja Turnšek
}

https://doi.org/10.20867/tosee.05.39

\begin{abstract}
Purpose - The study presents examples of good practice, which use innovative tourism products to extend their visiting season. These destinations are Island and Slovenia. Both countries have their high season in summer due to more agreeable weather conditions and warmer climate. Hence, the need for the prolonged season provided creative ideas, like transforming production factories into tourist attractions, and furthermore transform mere sightseeing of these premises into tourism experiences.

Methodology - The paper introduces a case study of two companies - from South Iceland is Friđheimar and from Slovenia company Paradajz d.o.o. The case study was delivered through indepth interviews with the company representatives and field observation in the factory tour itself. It supplied data about both providers and their industrial tourism practices with which benchmarking analysis was made.

Findings - The results suggest that such tourism products focus mostly on the education and aesthetics dimension of experience design, while escapism and entertainment dimension remain a challenge together with the challenge of overall theming of sustainability and geothermal energy. However, use of industrial tourism products has been a success in extending the tourist season into colder months and adding value to the business model.

Contribution - The study also highlights the issue of sustainability while both companies use geothermal energy to heath their greenhouses. The use of green energy is a contribution to sustainable development of tourism. Authors propose to promote further intertwinement of innovation and sustainability as presented in this case study in order to create a richer tourism experience.

Keywords Industrial tourism, experience economy, geothermal energy, innovative tourism products, experience design
\end{abstract}

\section{INTRODUCTION}

Tourism as an important economic sector contributes to socio-economic progress, but the residents' well-being depends on the quality of the tourism offer and on the revenues, it produces (UNWTO, n.d.a). However, tourism is strongly affected by seasonality, which causes higher revenues and lower quality of life in high season and lower revenues but better quality of life in lower season. Seasonality can be defined as a temporal imbalance in the phenomenon of tourism, which may be expressed in terms like the number of visitors, expenditure of visitors, traffic on the highways and other forms of transportation, employment and admission to attractions (Butler 2001, 5). Seasonality has long been an important topic in the field of tourism studies (Bar-On, 1975) and it is still one of the issues that intrigue the tourism industry (Rossello and Sanso 2017; 
ToSEE - Tourism in Southern and Eastern Europe, Vol. 5, pp. 507-520, 2019

B. Pavlakovič, M. Turnšek: ADDING VALUE WITH EXPERIENCES: INDUSTRIAL TOURISM AND ...

Turrión-Prats and Duro 2018; Ferrante, Lo Magno, and De Cantis 2018). It is also recognized by European Commission $(2007,2010,2015)$ by specific programs encouraging an extension of the tourist season and hence stimulating competitiveness in the European tourism sector.

Ferrante, Lo Magno, and De Cantis (2018) highlight the effects of seasonality, which extent from economic effects (the inefficient use of tourism resources, the overcrowding of destinations and attractions during peak demand periods and lack of capacity, increases in prices in the peak season, with a negative impact on a consumer's perception of value and seasonality in the labour market), environmental effects (damage to vegetation and fauna, disturbance of water supply and waste management) to sociocultural effects (a negative impact on residents due to overcrowding and lack of destination's resources for themselves). As Butler (2014) suggested, there are a number of actions which can be taken to diminish the effects of seasonality, for example extending the season, offering different attractions out of season, revamping the destination, making the destination unique and prestigious, adding a second main season or adding non-conventional tourist attractions. The main focus in therefore on creating an innovative tourism products and experiences that will attract tourists through the whole year and extend the tourist season from its summer or winter peaks.

Based on these findings the main objective of the study is to present two case studies that offer new types of tourism, which can be regarded as tourist season extenders. First case study is from Iceland, European country located on an island in the North Atlantic Ocean, and the second case study is from Slovenia, southern Central Europe country. Iceland has experienced a continuous increase in the number of visitors for the last three decades and has witnessed an almost exponential growth in inbound tourism since 2010 (GilAlana and Huijbens 2018). Authors demonstrate that the highest values have been obtained in the months of July and August. Baum and Lundtorp (2001) argue that seasonality is important issue for cold-climate environments like Iceland and that they have to extend existing tourist season (e. g. from summer to September) and develop tourism on new markets (e. g. for seniors or festival lovers). Similarly, Slovenian tourism has also a strong seasonal character, which marks high season in summer months from May until October (Šegota and Mihalič 2018). Hence, the need for the prolonged season at these destinations inspired creative ideas like transforming production factories into tourist attractions and furthermore transform mere sightseeing of these premises into tourism experiences. The paper aims to present industrial tourism at both destinations, starting with the literature review of industrial tourism and experience economy concepts, followed by its innovative intertwinement with sustainable practices such as using geothermal energy.

\section{INNOVATIVE TOURISM PRODUCT - INDUSTRIAL TOURISM}

Readiness for novelty is a driving force of western world since people accept and seek innovation in industry, education, family life, the arts, social relationships, and the like (Goeldner and Ritchie 2003). This change of the social climate is noticeable also in travel demand as people move away from the traditional resorts to new and unfamiliar places or to places that offer innovative tourism products. Innovation is described in the terms 
ToSEE - Tourism in Southern and Eastern Europe, Vol. 5, pp. 507-520, 2019

B. Pavlakovič, M. Turnšek: ADDING VALUE WITH EXPERIENCES: INDUSTRIAL TOURISM AND ...

of newness, focus and attributes (Hall and Williams 2008) or with the words of Kanter (in Hall and Williams 2008) innovation refers to the process of bringing any new, problem solving idea into use. Innovation is the generation, acceptance and implementation of new ideas, processes, products or services. Hence the capacity to change and adapt is central to development and firms that can read, anticipate, and respond to the specific needs and desires of high-quality niche or special-interest markets in innovative ways will have great opportunities for success (Goeldner and Ritchie 2003). Innovation is important for the whole tourism sector, whether in transport, entertainment or hospitality, at local or national level while the source of innovation often lies outside the sector itself (Hall and Williams 2008). Examples are improved air transport and the emergence of World Wide Web, which were originally developed for the military purposes. On the other hand, tourism sets new trends like promoting exotic cuisines or developing sharing economy.

One of the innovative trends is also a tourism product of industrial tourism, where tourists visit a factory, enter a tour and are acquainted with its production and its products. Industrial tourism is dynamic, interactive and different from usual forms of tourism since its focus are technology and knowledge that become the key innovative elements that draw most tourist attention (Jing 2012). Industrial tourism is defined by several authors (Frew 2000; Robinson in Jafari 2003; Otgaar, Van den Berg, Berger and Xiang Feng 2010; Vargas-Sánchez, Porras-Bueno and Plaza-Mejía 2014) as visits to companies, where productive activity is actually happening, to witness production processes in motion, to taste / experience the products or to learn about company's history. This kind of industrial tourism can be described as active industrial tourism (Rodríguez-Zulaica 2017). Meanwhile industrial tourism also encompasses visits to inoperative and abandoned industrial heritage sites, which can be defined as industrial heritage tourism (Hospers 2002).

Although industrial tourism is not a new activity and companies have hosted visitors even back in the late 19 / early 20 century (Frew 2000; Marsh 2008; MacCannell 2013), it is attaining increasing importance nowadays as a part of the cultural heritage in a growing number of destinations. Active or industrial heritage tourism is attractive to tourist since it represents a special on-site experience. Jia (2010) proposes that the concept of experience could be introduced into industrial tourism program design as its essence to create a special and interesting tourism experience to satisfy tourists' sensory and mental needs. $\uparrow$

\section{EXPERIENCE ECONOMY IN INDUSTRIAL TOURISM}

Pine and Gilmore $(1998,1999)$ claim that the last few decades have brought about a new stage in the economic progress from service economy into experience economy where "work is theatre and every business a stage" (Pine and Gilmore 1999). Adding experiences seems to be the current answer to the question of the ever-progressing search for adding value and thus increasing the price and distinguishing one's offer from the competition. Pine and Gilmore claim that not only tourism businesses for whom staging is the essential part of their business model (e.g. theme parks such as Disneyworld), but also other businesses are more and more in the business of staging experiences, thus 
ToSEE - Tourism in Southern and Eastern Europe, Vol. 5, pp. 507-520, 2019

B. Pavlakovič, M. Turnšek: ADDING VALUE WITH EXPERIENCES: INDUSTRIAL TOURISM AND ...

supporting the trend of the increase of the industrial tourism whereby businesses not only strive to sell commodities, goods or services, but also adding experiences. To take their famous "cake metaphor", in the experience economy parents neither make the birthday cake nor even throw the party. Instead, they spend $\$ 100$ or more to "outsource" the entire event to a business that stages a memorable event for the kids - and often throws in the cake for free (Pine and Gilmore 1998).

If we apply Pine and Gilmore's (1998) approach to metaphorically represent the historical progression of adding value to the business of selling tomatoes, we can argue that there are historically at least four types of tomato growing businesses that can according to Pine and Gilmore be also understood as stages of economic development (see Image 1).

Image 1: The progression of economic value in producing tomatoes

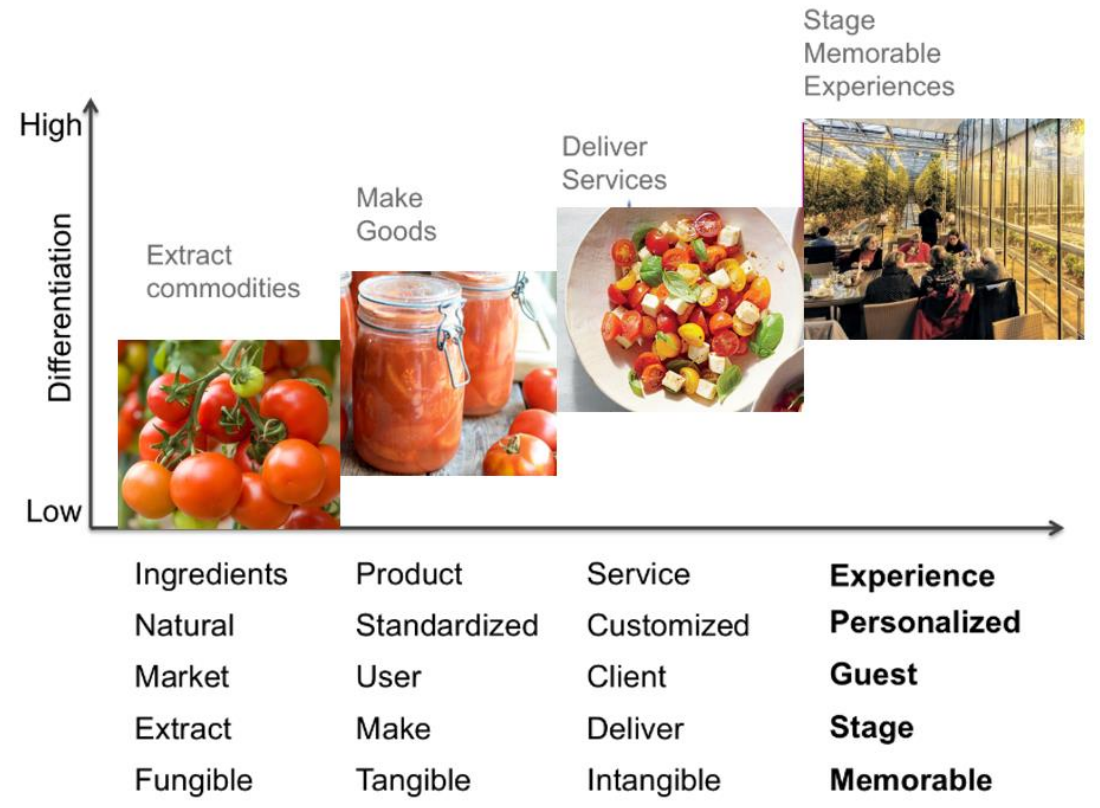

Source: Based on Pine and Gilmore 1998

If we apply Pine and Gimore's "cake metaphor" to the case of tomatoes, we can argue that in the agrarian economy, the added value was narrowed only to selling the commodities - tomatoes. As the goods-based industrial economy advanced, farmers and other specialized companies added value by transforming tomatoes into standardized products, for example canned tomatoes. Later, when the service economy took hold, farmers also added services, such as preparing meals from the tomatoes. Finally, the experience economy means that farmers add value through providing experiences memorable events. 
ToSEE - Tourism in Southern and Eastern Europe, Vol. 5, pp. 507-520, 2019

B. Pavlakovič, M. Turnšek: ADDING VALUE WITH EXPERIENCES: INDUSTRIAL TOURISM AND ...

An experience is defined by Pine and Gilmore (1998) as a result of the process in which a company intentionally uses services as the stage, and goods as props, to engage individual customers in a way that creates a memorable event (for example transforming a taxi ride from a mere service of getting from point A to point $\mathrm{B}$ into an entertaining event enjoyed for its own value). Pine and Gilmore (1998) were mostly concerned with the question of how to design an experience in a way that "sells" and thus be staged in a memorable way. They advise to theme the experience, harmonize impressions with positive cues, eliminate negative cues, mix in memorabilia and engage all five senses. While commodities, goods, and services are external to the buyer, experiences are inherently personal, existing only in the mind of the guests deriving from the interaction between the staged event (like a theatrical play) and the individual's state of mind. Pine and Gilmore propose two dimensions according to which experiences can be analysed. The first is guest participation; the level to which guests affect the performance. The second is immersion; the level of environmental relationship, that unites customers with the event or performance. The two dimensions serve to sort experiences into four broad categories or realms which themselves become dimensions of experiences, since some attractions such as the Disney World, manage to include all four areas: entertainment, education, escape and aesthetic dimension.

Adding experiences to farming has long been the domain of research interest in agritourism, whereby the focus has been on adding experiences on smallholders' farms. They have mostly offered content such as local cuisine, animal petting and experiencing life on the farm and in touch with nature and tradition. What this paper analyses, however, is the new type of agritourism - one that does not base on smallholding farmers, but on high-tech hydroponic farming, where the operations are often more similar to industrial tourism than to traditional agritourism farms, or are a combination of both.

\section{INTERTWINEMENT OF INNOVATION AND SUSTAINABILITY}

Ever since the Rio Earth Summit in 1992, tourism organizations promoted the formulation of environmentally sound and culturally sensitive tourism programs as a strategy for sustainable development (Spenceley, Kohl, McArthur, Myles, Notarianni, Paleczny, Pickering and Worboys 2015). Sustainable development of tourism was regarded as a balanced approach to economic, social and environmental development. According to UNWTO (n.d.b) it can be defined as "Tourism that takes full account of its current and future economic, social and environmental impacts, addressing the needs of visitors, the industry, the environment and host communities". As such sustainable tourism should make optimal use of environmental resources while being ecological and helping to conserve natural heritage and biodiversity; respect the socio-cultural authenticity of host communities (built and living cultural heritage, traditional values); ensure socio-economic benefits to all stakeholders (stable employment and incomeearning opportunities, social services and contributing to poverty alleviation) (World Tourism Organization 2004).

When tourist destinations integrate sustainability in their core philosophy, they also strive to be more innovative to accomplish sustainable criteria. Koščak (2018) suggests, that they provide different tourist experiences that range from culture, art, sport, to 
ToSEE - Tourism in Southern and Eastern Europe, Vol. 5, pp. 507-520, 2019

B. Pavlakovič, M. Turnšek: ADDING VALUE WITH EXPERIENCES: INDUSTRIAL TOURISM AND ...

gastronomy and relaxation. Next, they also target different target markets as potential tourists. Destinations endeavour also for higher quality products that are environmental friendly or even encourage tourist to act ecologically. One of sustainable and innovative ways of providing tourism products is a tourism offer based on the use of geothermal energy.

Geothermal energy in both Iceland and Slovenia has long had an important role in the geothermal water based tourism. For both countries, this is the prime tourism product, attracting high extent of tourists in geothermal spas and natural hot-water bathing areas. Not much has been done, however, on finding other innovative ways of combining the usage of geothermal energy with tourism. We thus see the shift towards combining geothermal food production and tourism as a potentially important and innovative new trend in finding other ways for geothermal use, and thus extending the sustainability of the geothermal energy use.

\section{USED METHODS}

The paper introduces a case study of two companies - from Iceland is Friđheimar Company and from Slovenia Paradajz d.o.o company. The case study was delivered firstly through interviews with the company representatives. Research question were sent to them via e-mail and we got the responses from the responsible persons at the sites. From Friđheimar we were in contact with its owner, and from Paradajz d.o.o we were in contact with the visitors' manager. As a second method we used a field observation in the factory tour itself. Friđheimar Company tour took place in June 2018 and Paradajz d.o.o Company took place in November 2018. We have also used secondary data from statistical offices of Iceland and Slovenia. All the supplied data about both providers, their industrial tourism practices and the general data about tourism figures in both countries formed a pool for a final benchmarking analysis.

\subsection{Site descriptions}

The Icelandic company Fridheimar is a family owned company, with a yearly tomato production of approx. 370 tons. They use geothermal energy for hydroponic production. From initial small greenhouses, they increased their greenhouses to first 1 and later to 1.6 hectares, with the current state being more than 4 hectares. The first visitors' greenhouse facilities were built in 2011, and extended in 2013 (see Image 2). Additionally, the farm attracts tourist with an equestrian centre (Friedheimar 2019). The farm is located within the so-called "Golden Circle" travel route in the south of Iceland, thus giving it an important competitive advantage in attracting visitors. 


\section{Image 2: Fridheimar tomato farm in Iceland}

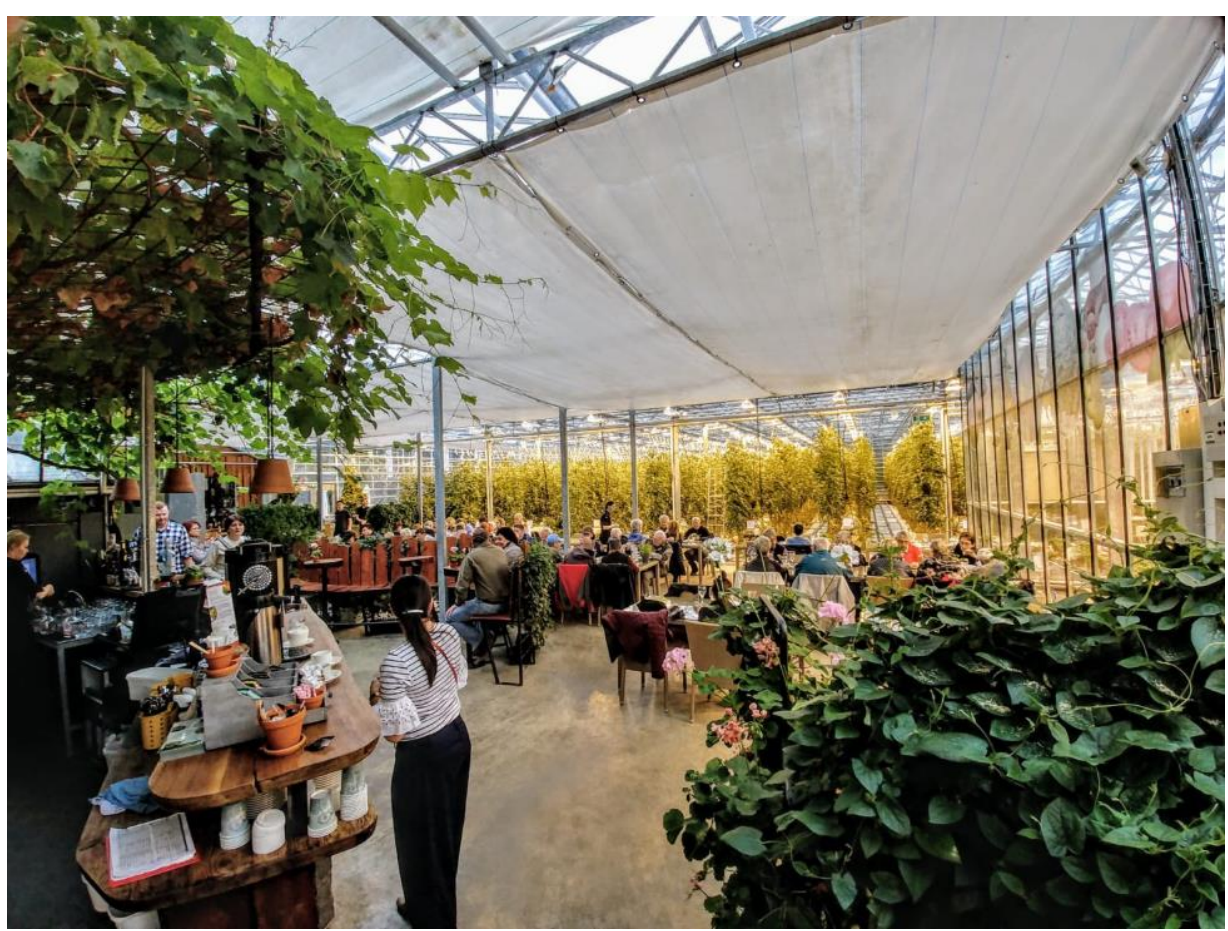

Source: Carlos Espinal 2018

Slovenian company Paradajz d.o.o is settled in the North East part of Slovenia, in Prekmurje region. It was founded in 2007, but the expansion of the production and the marketing boom started in 2012 with the launch of the tomato brand Lušt. From initial 4 hectare of greenhouses, they have grown to 9 hectare of greenhouses, where they grow multiple varieties of tomatoes. The company employs approximately 50 people, but they also cooperate in the Lušt association, where they combine forces with the local farmers, who grow also other vegetables like garlic, onion, potato, cabbage and pepper. Paradajz d.o.o is settled in the region with high geothermal potential and the company has its own geothermal hole, which they use to heath greenhouses in the colder months (Paradajz d.o.o. 2019). In April 2018, they have opened a visitor centre and a sample tomato greenhouse where they offer guided visits and tomato tastings for visitors (see image 3 ). 


\section{Image 3: Lušt sample tomato greenhouse in Slovenia}

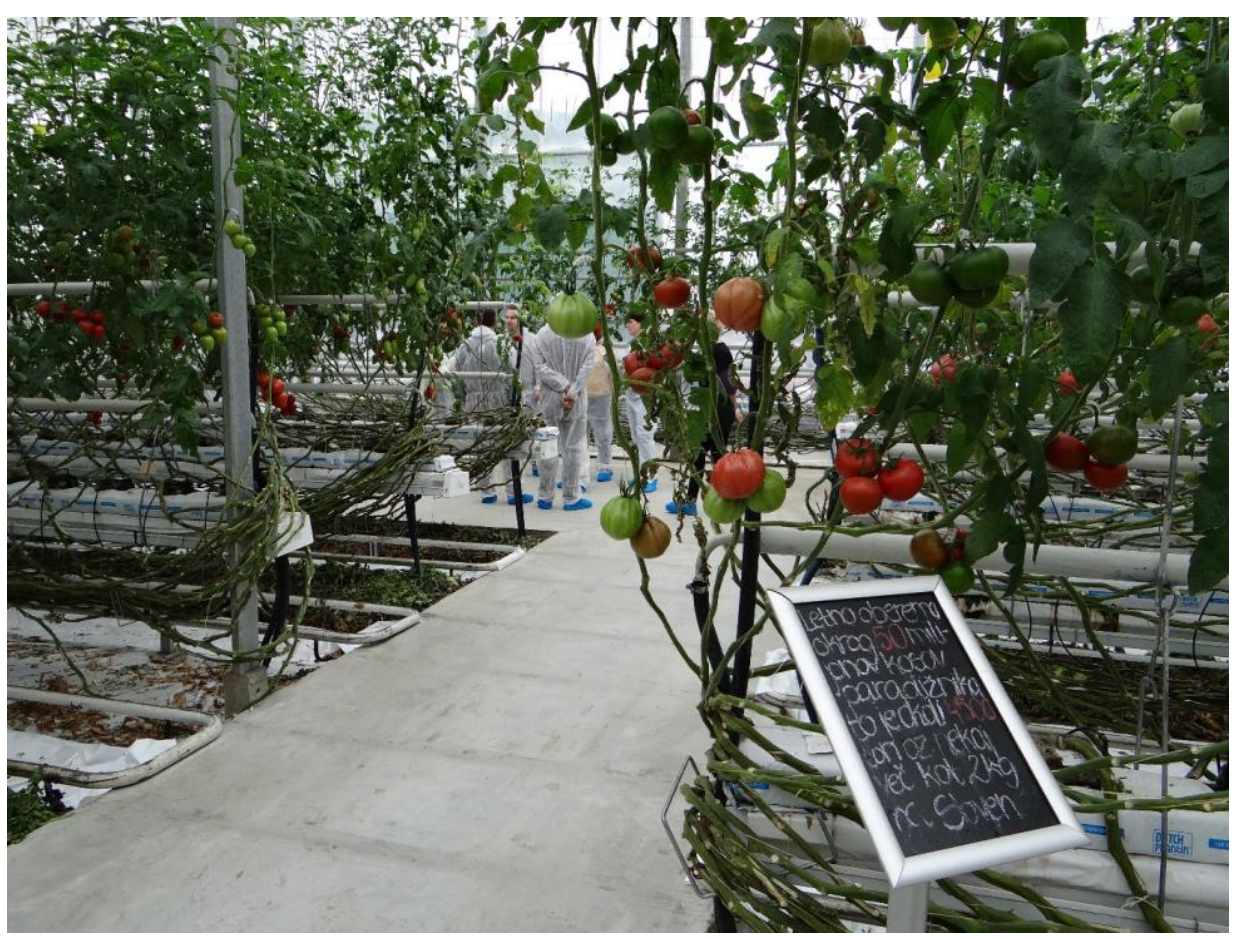

Source: Barbara Pavlakovič 2018

\section{RESULTS}

Industrial tourism in greenhouses offers a special insight into the production of vegetables and fruits and also into use of geothermal energy. As such our first focus was on the tourist product itself, how it addresses visitors and which experience dimensions could we recognise. Our second interest was to study, how examined case studies dealt with the seasonality.

\subsection{Experiencing tomatoes}

Islandic company Friđheimar offers visits to their greenhouses, their restaurant with a bar, and the horse stables. Their main interest is to present and explain how tomatoes are grown in Iceland both now and to some extent in history. The product shows the visitors how they use the geothermal powers to grow food. This presents the foundation for their restaurant and souvenir shop offer which is all together named a food experience. At first, they welcomed only groups, but now they have also individual guests. Among them are many students with their teachers but also just people who are visiting Iceland, taking the route of the "Golden Circle" and lunch at Friđheimar. When groups arrive, they first have a 10-15 minutes speech about how Friđheimar grows the tomatoes in Iceland with the help of the nature and geothermal energy. Next, the visitors can have lunch if they 
ToSEE - Tourism in Southern and Eastern Europe, Vol. 5, pp. 507-520, 2019

B. Pavlakovič, M. Turnšek: ADDING VALUE WITH EXPERIENCES: INDUSTRIAL TOURISM AND ...

prefer and many go to see the horses. Individual guests have a short presentation of the place at the table before seeing the menu, while the company efforts are to provide a good food experience for every guest.

The product is very much building on Pine and Gilmore's (1998) advice to theme the experience, with the overall theme being the tomatoes. The visitors can observe the tomato production faculties while enjoying the sun at the restaurant inside of the greenhouse. They can also learn about tomato and greenhouse production in Iceland through history (if the group is guided via the guide, otherwise via the information billboards). And most markedly, they can even try the local beer made partly from tomatoes, with a cherry tomato floating in the glass itself. In terms of the four dimensions of an experience (aesthetics, education, escapism and entertainment), the product builds on the first two, but neglects the second two dimensions. Most emphasis is put on the aesthetics dimension of the product with its main value proposition being the restaurant and the bar positioned in the modern glass greenhouse environment. The guest can thus enjoy the good mood or good food while having an overview of the tomato production facilities behind the glass. The educational dimension is cared for either via guide interpretation (in case of group visits), but the individual visitors are left to educate themselves about the history of the farm of the greenhouse production via a number of information billboards positioned within the visitors' centre. However, we could not find any signs of the entertainment or the escapism dimensions to be directly addressed within the design of the product.

Much alike is the experience at Paradajz d.o.o. or to be precise at their so-called "Cute homestead" (Luštna domačija). Visitors are welcomed to come to a shop / restaurant and to visit a sample greenhouse since the production greenhouses are closed for the public. The company's goal is to present their tomato growing method with the use of greenhouses, geothermal energy and natural substrate. They put emphasis on natural growing methods like populating greenhouses with bumblebees for fertilization and not using harmful spray preparations. Paradajz d.o.o. welcomes visitors of all ages, groups and individuals. They have noticed that among visitors there are many primary and high school groups, university students and general tomato lovers, who just want to learn about the fruit. Visit lasts approximately one hour. Firstly, one of the guides takes the visitors into a sample greenhouse where she presents the tomatoes and the growing technique. Next, the visitors go to the restaurant, where they have tomato tasting, visit tomato shop or order something from the bar.

Using field observation method we have learned about the experience Paradajz d.o.o. provides for their visitors. First of all, accordingly to the objectives of the company, the most noticeable is the education experience dimension. Visitors learn about different varieties of tomatoes since the sample greenhouse hosts 100 tomato varieties - from small cherry tomato to big ox-heart tomato. Tomatoes are there to observe, touch and taste since visitors can pick and eat any tomato they like from the sample greenhouse. Guide also talks about the tomato varieties, the growing methods, and about the use of geothermal energy. She also exposes the bumblebees and their beehives, which can be seen among tomato plants. Gained tomato knowledge can be tested during the tomato tasting in the restaurant, where the guide asks questions about the eaten varieties and about visitors' taste. Secondly, the aesthetics dimension is also highly perceptible. The 
ToSEE - Tourism in Southern and Eastern Europe, Vol. 5, pp. 507-520, 2019

B. Pavlakovič, M. Turnšek: ADDING VALUE WITH EXPERIENCES: INDUSTRIAL TOURISM AND ...

company is set in the green soundings of Prekmurje region, full of fields and flora. Visitor centre is new and tastefully constructed and arranged, and the greenhouse is full of orderly grown tomato plants, providing captivating green and red colour mixture. The greenhouse is due to its structure very bright and warm and very clean, since tomatoes are grown from a substrate in a bag. Moreover, when tasting tomatoes in the restaurant, the fruits are attractively presented on a serving plate, ready to be eaten. The shop is also nicely arranged and offers different shades of red tomatoes. Hence, colours are the most aesthetical element of this offer. Thirdly, the entertainment dimension is somewhat less visible in the case of visiting Paradajz d.o.o. The guide's speeches cannot be regarded as fun, since they are much more educational and there is no other entertainer on the spot. Perhaps the most amusing moment happens at the beginning of the visit, when the visitors have to put on a coverall and protective slippers. Dressed up visitors in white coverall and blue slippers can take photographs before entering the greenhouse and this moment causes great laughter while making this "alien-like" pose. Finally, the escapist dimension is also not distinguishable at the first moment. However, it can be noticeable as a quest for authentic life of growing food and using land for humankind survival. Visits to food production facility bring us back to our roots as farmers, and watching other people grow tomatoes, gives us an experience of something extraordinary for nowadays office workers. Even though in the Paradajz d.o.o. sample greenhouse there are no farm workers, the glass walls of the greenhouse offer an insight into the production greenhouses, where the employees can be seen during their actual work. In this way, the visitors can participate in the escapist experiences.

\subsection{Visitor seasons in greenhouses}

Visitor season of a tourism destination is an important factor in managing the destination. Therefore, our first goal was to examine the seasons in both countries - Iceland and Slovenia. We have gathered data from statistical offices for the years 2016, 2017 and 2018. Both countries are comparable regarding the number of visitors since in the year 2018 Iceland had 5,620,120 arrivals and Slovenia 5,624,474 arrivals, while the number raised steadily over past years in both countries. Table 1 shows the monthly tourist arrivals numbers for Iceland and Table 2 shows the monthly tourist arrivals numbers for Slovenia.

Table 1: Monthly tourist arrivals numbers for Iceland

\begin{tabular}{|l|l|l|l|l|l|l|}
\hline & Jan & Feb & Mar & Apr & May & Jun \\
\hline 2016 & 129615 & 189743 & 232511 & 192123 & 311872 & 617500 \\
\hline 2017 & 205233 & 258735 & 299824 & 266145 & 345007 & 645386 \\
\hline 2018 & 226906 & 300697 & 337874 & 238953 & 364849 & 677586 \\
\hline & & & & & & \\
\hline & Jul & Aug & Sep & Oct & Nov & Dec \\
\hline 2016 & 919677 & 840662 & 455576 & 293040 & 228159 & 214057 \\
\hline 2017 & 933515 & 832912 & 483179 & 333875 & 242539 & 218236 \\
\hline 2018 & 975404 & 962374 & 686936 & 370898 & 252502 & 225141 \\
\hline
\end{tabular}

Source: Statistics Iceland n.d. 
ToSEE - Tourism in Southern and Eastern Europe, Vol. 5, pp. 507-520, 2019 B. Pavlakovič, M. Turnšek: ADDING VALUE WITH EXPERIENCES: INDUSTRIAL TOURISM AND ...

Table 2: Monthly tourist arrivals numbers for Slovenia

\begin{tabular}{|l|l|l|l|l|l|l|}
\hline & Jan & Feb & Mar & Apr & May & Jun \\
\hline 2016 & 212951 & 229763 & 249460 & 272384 & 337699 & 382713 \\
\hline 2017 & 230696 & 240027 & 269553 & 348812 & 362848 & 487981 \\
\hline 2018 & 249011 & 249170 & 324557 & 386441 & 469183 & 570462 \\
\hline & & & & & & \\
\hline & Jul & Aug & Sep & Oct & Nov & Dec \\
\hline 2016 & 585044 & 676244 & 426699 & 326110 & 218990 & 252296 \\
\hline 2017 & 679743 & 765332 & 458824 & 365780 & 239674 & 279010 \\
\hline 2018 & 825363 & 943920 & 585659 & 423235 & 282998 & 314475 \\
\hline
\end{tabular}

Source: SURS n.d.

As the statistical data confirms, the high season on Iceland is the summer season (June, July and August), representing over $51 \%$ of all tourist arrivals in 2016 and slightly descending to $47 \%$ in 2018. The lowest season is the winter season (December, January and February) with $12 \%$ of all tourist arrivals in 2016 and slightly rising to $13 \%$ in 2018. The spring season (March, April and May) with $16 \%$ of all tourist arrivals in 2016 and with $17 \%$ in 2018 is close to a bit stronger autumn season (September, October and November) with $21 \%$ of all tourist arrivals in 2016 and with $23 \%$ in 2018.

Similarly, the high season in Slovenia is also the summer season with over $39 \%$ of all tourist arrivals in 2016 and slightly rising to $42 \%$ in 2018. The lowest season is the winter season with $17 \%$ of all tourist arrivals in 2016 and slightly descending to $14 \%$ in 2018. The spring season represents $21 \%$ of all tourist arrivals in 2016 and in 2018, while the autumn season represents $23 \%$ of all tourist arrivals in 2016 and in 2018.

Although the number slightly vary, when comparing both countries, Iceland proved to be a bit more summer destination and Slovenia - even though its high season is still summer - has more equally distributed arrivals among other three seasons. As the fact that both counties are seasonal was verified, our study aimed to examine, if the innovative tourism product like industrial tourism in tomato greenhouses could extend the visiting season to other months. As company Friđheimar answered, their visiting season is all year round, but the high season is approximately from May until October, while November until January are being the slowest months. All together, they received approximately 175.000 guests in 2018 and around 160.000 in 2017. Company Paradajz d.o.o. answered that their visiting season lasts from March until December, while in January and February there are no tomatoes to be seen. In 2018, their first year of operation, they have noticed the biggest tourist demand in April, May and June, July and August were a bit slow, followed by again more visited September, October, November and December. Altogether, there were approximately 7.000 visitors in 2018 . 
ToSEE - Tourism in Southern and Eastern Europe, Vol. 5, pp. 507-520, 2019

B. Pavlakovič, M. Turnšek: ADDING VALUE WITH EXPERIENCES: INDUSTRIAL TOURISM AND ...

\section{CONCLUSION}

The results suggest that examined industrial tourism products focused mostly on the education and aesthetics dimension of experience design, while escapism and entertainment dimension remain a challenge. Facts about tomatoes and about growing tomatoes were the centre point of both presentations since visitors seemed to value greatly the extension of their tomato knowledge. Additionally, the aesthetics dimension plays an important role in attracting visitors and creating positive atmosphere where visitors enjoy spending their free time. Intensive colours, modern architecture and warm greenhouse air are the main aesthetic charms. On the other hand, companies do not put emphasis on escapism and entertainment dimension. The visited industrial tourism products cannot be described as fun or self-expressing and therefore are missing two dimension of full experience design. In order to provide memorable overall experience, companies could offer entertainment in form of children game, a funny mascot, humorous videos or something alike. In terms of escapism, tomato growing or cooking classes could be offered, however there are plenty other opportunities to offer to the visitors for their self-expression together with the overall theming of sustainability and geothermal energy.

Our second focus was on seasonality. The use of industrial tourism products has been a success in extending the tourist season into colder months and adding value to the business model. Both countries Iceland and Slovenia are mostly summer season destinations, while both tomato companies stated that their high season is not only summer, but also spring and autumn. In fact, summer season is actually a bit slower season for Slovenian company, while spring and autumn season being the busiest. This research showed that tourists could be attracted to destinations also in other seasons outside the main rush. Innovative tourism products are attractive and present an effective pull moment for tourists.

Overall, important contribution of this study is also highlighting the issue of sustainability while both companies use geothermal energy to heath their greenhouses. The use of green energy could be another pull factor and a contribution to sustainable development of tourism. Given these points, we propose to promote further intertwinement of innovation and sustainability as presented in this case study in order to create a richer tourism experience.

\section{ACKNOWLEDGEMENTS}

This research was made under the Geofood project dissemination activity. The Geofood project is supported through the ERANET Cofund GEOTHERMICA project (Project no. 731117), from the the European Commission, The Research Council in Iceland (Rannis), Netherlands Enterprise Agency(RVO), the Ministry of Infrastructure and Ministry of the Environment and Spatial Planning, Republic of Slovenia. The consortium partners include Wageningen University \& Research, LandIng Aquaculture, Ammerlaan (Netherlands), University of Iceland, Samraekt (Iceland), University of Maribor and the Municipality of Brežice (Slovenia). 
ToSEE - Tourism in Southern and Eastern Europe, Vol. 5, pp. 507-520, 2019

B. Pavlakovič, M. Turnšek: ADDING VALUE WITH EXPERIENCES: INDUSTRIAL TOURISM AND ...

\section{REFERENCES}

Bar-On, R. R.V. (1975), Seasonality in Tourism: A Guide to the Analysis of Seasonality and Trends for Policy Making, The Economist Intelligence Unit Limited, London.

Baum, T. and Lundtorp, S. (2001), Seasonality in Tourism, Routledge, London.

Butler, R. W. (2001), "Seasonality in tourism: Issues and implications", in Baum, T. and Lundtorp, S. (Eds.), Seasonality in Tourism, Routledge, London, pp. 5-21.

Butler, R. (2014), Addressing seasonality in tourism: the development of a prototype, Conclusions and Recommendations resulting from the Punta del Este Conference, May 2014. Report for UNWTO, viewed 17 January 2019, http://cf.cdn.unwto.org/sites/all/files/pdf/final_notes_richard_butler.pdf

European Commission (2007), Communication from the commission - agenda for a sustainable and competitive European tourism, viewed 16 January 2019, http://eur-lex.europa.eu/legal-content/EN/ALL/?uri=CELEX:52007DC0621

European Commission (2010), Communication from the Commission to the European Parliament, the Council, the European Economic and Social Committee and the Committee of the Regions - Europe, the world's No 1 tourist destination - a new political framework for tourism in Europe, viewed 16 January 2019, http://eur-lex.europa.eu/legal-content/EN/ALL/?uri=celex:52010DC0352

European Commission (2015), Supporting competitive and sustainable growth in the tourism sector, viewed 16 January 2019, https://ec.europa.eu/easme/sites/easme-site/files/documents/cos-tour-2015-304_call_description.pdf

Ferrante, M., Lo Magno, G. L. and De Cantis, S. (2018), "Measuring tourism seasonality across European countries", Tourism Management, Vol. 68, pp. 220-23 https://doi.org/10.1016/j.tourman.2018.03.015

Frew, E. A. (2000), Industrial tourism: a conceptual and empirical analysis (doctoral dissertation), Victoria University.

Friedheimar (2019), Friedheimar, viewed 10 February 2019, https://friedheimar.is/en

Gil-Alana, L.A. and Huijbens, E.H. (2018), "Tourism in Iceland: Persistence and seasonality", Annals of Tourism Research, Vol. 68, pp. 20-29.

Goeldner, C.R. and Ritchie, J.R.B. (2003), Tourism: Principles, Practices, Philosophies, Wiley, Hoboken (N. J.).

Hall, M.C. and Williams, A.M. (2008), Tourism and Innovation, Routledge, London, New York.

Hospers, G.-J. (2002), "Industrial Heritage Tourism and Regional Restructuring in the European Union", European Planning Studies, Vol. 10, No. 3, pp. 397-404.

Jafari, J. (2003), Encyclopedia of tourism, Routledge, London. New York.

Jia, Y. (2010), "Analysis and Suggestions on Chinese Industrial Tourism Development", International Business Research, Vol. 3, No. 2, pp. 169-173.

Jing, J. (2012), "Key Factors and Calculation Model of Experience Innovation Management - The discussion of industrial tourism under the experience economy", Second International Conference on Business Computing and Global Informatization (BCGIN), October 2012, pp. 465-468.

Koščak, M. (2018), "Smernice za prihodnji razvoj trajnostnega in odgovornega turizma na projektnem območju - teoretična izhodišča” in Koščak, M. and Pavlakovič, B. (Eds.), Razvojni program celovitega in trajnostnega razvoja območja Prezida in Gorskega kotarja, Univerzitetna založba Univerze v Mariboru, Maribor.

MacCannell, D. (2013), The tourist: A new theory of the leisure class. University of California Press, Berkeley, Los Angeles, London.

Marsh, A.C. (2008), The ultimate vacation: watching other people work, a history of factory tours in America, 1880-1950 (doctoral dissertation), Johns Hopkins University

Otgaar, A.H.J., Van den Berg, L., Berger, C. and Xiang Feng, R. (2010), Industrial Tourism: Opportunities for City and Enterprise, Ashgate Publishing, Ltd, Farnham, Burlington.

Paradajz d.o.o. (2019), Lušt, viewed 6 February 2019, https://www.lust.si/

Pine, B.J., and Gilmore, J.H. (1998), "Welcome to the experience economy", Harvard business review, Vol. 76, pp. 97-105.

Pine, B.J., and Gilmore, J.H. (1999), The experience economy: work is theatre \& every business a stage, Harvard Business Press, Boston, Massachusetts.

Rodríguez-Zulaica, A. (2017), "Redefiniendo el concepto de Turismo Industrial. Comparativa de la terminología en la literatura castellana, francesa y anglosajona", Revista de Turismo y Patrimonio Cultural, Vol. 15, No. 2, pp. 311-318.

Rossello, J. and Sanso, A. (2017), "Yearly, monthly and weekly seasonality of tourism demand: A decomposition analysis", Tourism Management, Vol. 60, pp. 379-389. 
ToSEE - Tourism in Southern and Eastern Europe, Vol. 5, pp. 507-520, 2019

B. Pavlakovič, M. Turnšek: ADDING VALUE WITH EXPERIENCES: INDUSTRIAL TOURISM AND ...

Spenceley, A., Kohl, J., McArthur, S., Myles, P., Notarianni, M., Paleczny, D., Pickering C. and Worboys G L. (2015), "Visitor management" in Worboys, G. L., Lockwood, M., Kothari, A., Feary, S. and Pulsford I. (Eds.), Protected Area Governance and Management, ANU Press, Canberra.

Statistics Iceland n.d., Accommodation, viewed 6 February 2019, https://statice.is/statistics/business-sectors/tourism/accommodation/

SURS n.d., Podatkovni portal SI-STAT, viewed 6 February 2019, https://pxweb.stat.si/pxweb/Database/Ekonomsko/Ekonomsko.asp

Šegota, T. and Mihalič, T. (2018), "Elicitation of tourist accommodation demand for counter-seasonal responses: Evidence from the Slovenian Coast", Journal of Destination Marketing \& Management, Vol. 9, pp. 258-266.

Turrión-Prats, J. and Duro, J.A. (2018), “Tourist seasonality and the role of markets”, Journal of Destination Marketing \& Management, Vol. 8, pp. 23-31.

UNWTO n.d., Why tourism?, viewed 17 January 2019, http://www2.unwto.org/content/why-tourism

UNWTO n.d.b, Definition, viewed 6 February 2019, http://sdt.unwto.org/content/about-us-5

Vargas-Sánchez, A., Porras-Bueno, N. and Plaza-Mejía, M. Á. (2014), "Industrial tourism”, in Jafari, J. and Xiao, H. (Eds.), Encyclopedia of Tourism, Springer, Cham, viewed 30 July 2018 , https://doi.org/10.1007/978-3-319-01669-6_269-1

World Tourism Organization (2004), Indicators of Sustainable Development for Tourism Destinations: A Guidebook. World Tourism Organization, Madrid.

Barbara Pavlakovič, Teaching Assistant

University of Maribor, Faculty of Tourism

Cesta prvih borcev 36, 8250 Brežice, Slovenia

Phone: +3868 2056791

E-mail: barbara.pavlakovic@um.si

Maja Turnšek, PhD, Assistant Professor

University of Maribor, Faculty of Tourism

Cesta prvih borcev 36, 8250 Brežice, Slovenia

Phone: +3868 2054010

E-mail: maja.turnsek@um.si 